\title{
Exploring a retrospective narrative in Genesis 45:1-15
}

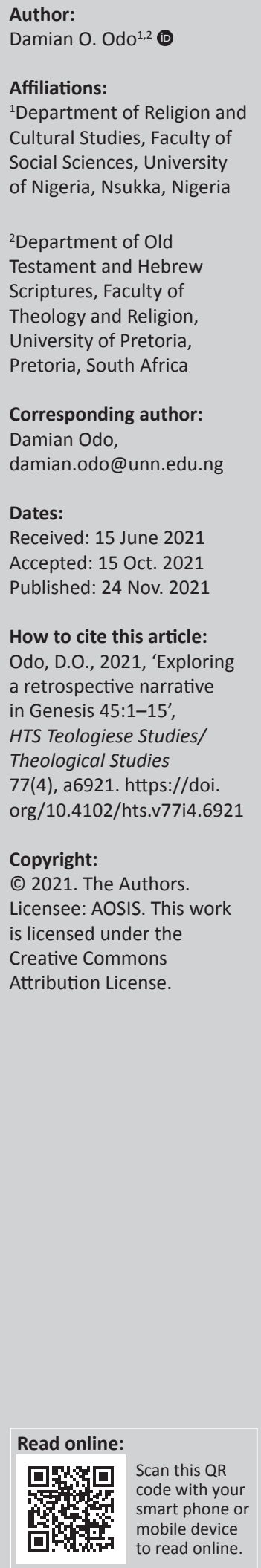

\section{Author:}

\section{Affiliations:}

Aepartment of Religion and Social Sciences, University of Nigeria, Nsukka, Nigeria

2Department of Old Testament and Hebrew University of Pretoria, toria, South Afric

\section{Damian Odo,}

Dates:

Received: 15 June 2021

Accepted: 15 Oct. 2021

How to cite this article: Odo, D.O., 2021, 'Exploring a retrospective narrativ in Genesis 45:1-15', Theological Studies 77(4), a6921. https://doi. org/10.4102/hts.v77i4.692

Copyright: Licensee: AOSIS. This work is licensed under the Creative Commons Attribution License.
Read online: mobile device to read onlin
The text of Genesis 45:1-15 belongs to the composition of Joseph's narrative. This literary unit has an affinity with Genesis 37 that records the filial crime of Joseph's brothers against him (Joseph) as they intend to solve their conflict through a heinous act. The literary composition of Genesis 45 has been studied by commentators and scholars of the Old Testament from diverse perspectives. However, none of the scholars have studied the text from the standpoint of a retrospective narrative. A retrospective narrative is a literary technique expressed in a literary construct when a narrator flashes back to a past event, recreates the discourse and brings the episode into the present.

Contribution: This article contributes to scholarship as it argues that the literary unit of Genesis 45:1-15 is encoded in a device of a retrospective narrative. This is found in verses 4-8 of the pericope as the narrator artistically recreates the filial crime of the brothers against Joseph in Genesis 37 when they sold him into slavery.

Keywords: Genesis 45:1-15; reconciliation; retrospective narrative; forgiveness; Genesis 37; evil act.

\section{Introduction}

Jacob's paternal favouritism (unfair preferential treatment to one person at the expense of another) towards Joseph apparently instigated his brothers' hatred against him in Genesis 37 (Bruce 1986:138). The special favours that Jacob showered on Joseph did upset his brothers. Obviously, Joseph's ego and the way he handled his father's shows of favour got under the skin of his brothers (DeJonge 2020:1). Arising from the above backdrop, a growing antipathy towards him was ensured. Hale (2007:184) maintained that Joseph's brothers conspired to kill him as soon as they saw him coming towards them at Dothan. However, Reuben, the eldest of the brothers, pleaded that Joseph's life be spared. Reuben's plea resulted in Joseph being sold out as a slave to the Ishmaelite traders at the plot of conflict in Genesis 37. Upon going to Egypt, he was re-sold to Potiphar, a vizier of Pharaoh. As the drama kept unfolding, the climax was attained when Joseph forgave his brothers of their evil act against him and reconciled with them in Genesis 45. Old Testament commentators and scholars have written extensively on Joseph's forgiveness and reconciliation with his brothers in Genesis 45 employing different perspectives. However, it is discovered that no scholar has approached the text of Genesis 45 in the orbit of a retrospective narrative. Hence, this article aims to employ the device of a retrospective narrative to read Genesis 45:1-15. This article argues that the narrator of Joseph's reconciliation with his brothers in Genesis 45 employs a device of retrospective narrative as he looks back on the heinous act of Joseph's brothers in Genesis 37 when they sold him out into slavery. A retrospective narrative is underscored in a literary construct when a narrator brings back the past events into the present. Assuaging the severity of his brothers' crime, Joseph theologically explicates that his brothers intended evil to him by selling him into slavery but God transposed their evil act into good.

\section{Retrospective narrative in Genesis 45}

The period of 19th-century CE witnessed an emergence of a fascinating literary device of retrospective narrative in the American literature. The retrospective narrative is expressed in a literary construct when a narrator talks about a past experience, in which he may have been the central figure (Barry 1970:366). Substantiating this view, Pen and Pad (2021:1) affirmed that when a narrator looks back on the past, he becomes the primary storyteller to the reader, and that storytelling voice becomes a specific lens through which the reader experiences the world of the story. A retrospective narrative is told from the point of view of a character looking back on past events (Kori 2021:1; Bran 1996:186-208). Selgin (2019:1-2) explained that a 
retrospective narrative enables a narrator to recreate the past into the present through which the reader experiences the world of the story.

Arguably, the device of retrospective narrative is employed by the author of Genesis 45 in verses $4-8$ as the narrator flashes back to the heinous act of Joseph's brothers against him in Genesis 37. The text of Genesis 45 belongs to the exposition of Joseph's narrative, which has been studied with various approaches by different scholars. ${ }^{1}$

\section{Literary and historical context of Genesis 45:1-15}

Delimitation of a biblical text is perhaps a point of departure of an exegetical study of a text. Ska (1991:1) explained that one of the tasks of a literary analysis is the delimitation of narrative units. Accordingly, Mundele (2012:33) aptly posited that 'a literary unit is a biblical passage that has significance in itself' A close look at the pericope of this study reveals that the remote literary context of the text has an interface with Genesis 37:39-43 and partly with some segments of Chapter 44 . The event that led to the reconciliation of the protagonist with his brothers in Genesis 45 has a link with what happened earlier in Chapter 37 when Joseph's brothers, at the stage of complication, attempt to solve their conflict through a heinous act (Alter 1981:174; Brodier 2001:360; Heffelfinger 2016:305; Kraut 2019:221; Krusschwitz 2012:394; Lambe 1999:55). This was when Jacob sent Joseph to the field to know how they were faring. Before Joseph arrived at Dothan, they sighted him coming towards them and rejoiced as they resolved to commit fratricide (Gn 37:18). However, instead of committing fratricide, they resolved to sell him out into slavery to the Ishmaelite caravans going to Egypt for 20 pieces of silver. Apparently, there would not have been any need for reconciliation in Genesis 45 if Joseph's brothers had not offended him by selling him into slavery. The tension, which had been brewing up in the narrative, exploded in Genesis 45 as Joseph suddenly unveiled his identity to the brothers and reconciled with them.

According to Bridge (2019:585), the immediate literary context of the pericope is embedded in 'strategies of extensive linguistic politeness' of Judah in the preceding chapter of Genesis 44. Arguably, Judah's emotive utterances in vv 33-34, which ended Chapter 44, really triggered Joseph's forgiveness and reconciliation with his brothers in Genesis 45. In fact, Judah's repentance and readiness to embrace the yoke meant for Benjamin led to Joseph's disclosure of his true identity to the brothers (Brien 1997:429; Krusschwitz 2012:409). Obviously, Genesis 45 is a continuation of Genesis 44; it has a direct affinity with the immediate preceding chapter. Logically speaking, the episode of Genesis 45 could not have been tenable if not for Judah's persuasive pathos of eloquence (Joosten 2016:21-23) in Chapter 44, which brought Joseph's sudden disclosure of his identity and the subsequent reconciliation with his brothers.

\section{The structure of Genesis 45:1-15}

The text of Genesis 45:1-15 brings Joseph, who is indispensable to the narrative plot, to the fore. Consequently, he stimulates all the attention on himself as he brings forward the course of the events in the pericope. The narrator of this literary unit implanted in the pericope a literary term known as a doublet. This literary tool was brought to the limelight when Joseph revealed himself the second time to the brothers, assuaged the severity of their evil act against him, and explained the whole affairs theologically to put them at ease.

The literary unit of this study is segmented into four structures. The first division (vv. 1-3) is laced with emotion. Joseph's disclosure to his brothers was coated with pathos. Joseph's emotional outburst witnessed in this unit was unmistakably stimulated by Judah's passionate appeal to the vizier of Egypt to spare their father, Jacob, the agony which going back to Canaan without Benjamin would cause him (Carson 2007:88). Joosten (2016:30) aptly expressed that foreseeing the unspeakable anguish that would envelop his father if Benjamin were to be left behind in Egypt; Judah presented an urgent appeal to Joseph, soliciting him to save Jacob the grief, which the loss of Benjamin would bring upon him. Judah, without hesitation, offered to become a substitute for his brother and to bear the burden of slavery in his stead. Substantiating this view, Bridge (2019:581) posited that the revelation of the heroic personage in Genesis 45 to his brothers was aroused by Judah's passionate appeal. Kannel (2015:57) wrote that Judah's readiness to be sacrificed for the apparent guilt of Benjamin stimulated Joseph's reconciliation with his brothers, for he was overcome by emotion upon hearing Judah's appeal and was compelled to reveal his identity to the brothers.

The second segment (vv. 4-8) deals with Joseph's second revelation to the brothers. Joseph's first disclosure to the brothers got them trembling in fear. As a result of this, they became dumbstruck before him and looked at him for mercy. The bewilderment of Joseph's brothers observed in the first sudden revelation (vv. 1-3) accelerated his second disclosure in order to put them at ease. Joseph perceived the inner torment that must have been springing up in his brothers, and thus kindly disclosed himself the second time to assure them that he had no intention to harm them for their past heinous act against him. Joseph utilised his second disclosure to convince his siblings that he had no plans for revenge because God had transposed their evil acts to further His saving purposes.

Interestingly, the third unit (vv. 9-13) speaks of the protagonist's imperative to the brothers to go back home and bring his father to Egypt. Finally, the last unit of the structure (vv. 14-15) underlines Joseph's reconciliation with his brothers. Judah's powerful and pathos evoking speech triggered Joseph's reconciliation with his brothers 
(Wenham 2003:55). With Judah's moving speech, Joseph accelerated the narrative to the climax as he wept and reconciled with them symbolically. The literary construct of Genesis 45:1-15, which celebrates Joseph's forgiveness and reconciliation with his brothers, is fashioned in a device of retrospective narrative.

\section{Close reading of Genesis 45:1-15}

The literary unit of Genesis 45:1-15 is perhaps the most interesting segment of Joseph's narrative in the entire composition of Joseph's story in the Old Testament. It is in this segment of Genesis that the climax of Joseph's narrative was attained. The first three verses of the pericope (vv. 1-3) serve as the first segment of the literary unit of Genesis 45:1-15.

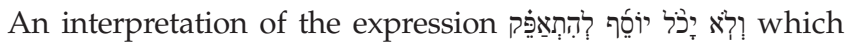
could be rendered as 'Joseph was unable to restrain himself' underscores an emotive embellishment of the utterance. Joseph in a fit of emotion became incapable to restrain himself anymore before his brothers. A careful reading of this part has shown that the narrator implanted a narrative technique of staircase construction in this unit. This device is used in a literary composition to intensify the narrative tension. In Joseph's narrative, the writer employed it to bring to the fore the most turning point of Joseph's exposition in order to establish an appropriate atmosphere of fear or curiosity. The narrative tension observed in Genesis 45:1-2 served as the preparatory scene to the disclosure of Joseph before his brothers in verse 3. Deffinbaugh (2020:2) avers that Joseph revealed himself to his brothers because they had evidenced real repentance, which made reconciliation possible. Joseph had all that were standing with him withdrew, thereby preparing the scene for the family affairs.

There is a discovery of a dramatic irony in this unit. Dramatic irony refers to a specific sort of situational irony, in which the audience knows what a character or group of characters does not know (Duke 1985:13). This literary technique is observed in Genesis 45:1-2. Joseph's brothers were standing with the vizier of Egypt when he commanded that all the attendants be withdrawn from him without knowing that the viceroy was their own brother - Joseph. The brothers were in the dark until he revealed himself to them in verse 3; however, the reader and Joseph knew. The knowledge of Joseph's real identity to his brothers triggered a paralysing fear in them. The subsequent scene of recognition then functions as a sort of denouement, resolving the dramatic tension (Culpepper 1998:72), which has been brewing up between Joseph and his brothers in the narrative. The unexpected utterances of Joseph to his brothers: 'I am Joseph! Is my father still alive?' were no doubt too much on them. The brothers became dumbstruck when they realised that the Egyptian governor and minister of agriculture was their own brother, Joseph, who they sold into slavery.

This article argues that the utterances of Joseph in verses $4-8$ are coated in a device of retrospective narrative. This affirmation holds true judging from the fact that in these verses, the narrator looks back into the past event as he recreates the filial crime of Joseph's brothers against him when they sold him into slavery in Genesis 37. Employing this device, the narrator politely passes to a reader the past evil deeds of Joseph's brothers against him. Recreating this event, the narrator in

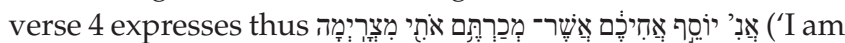
Joseph your brother whom you sold into Egypt'). A critical evaluation of this declaration of Joseph to the brothers underscores a technique of retrospective narrative. Through this device of bringing the past events into the present, the narrator cordially communicates to the reader, the evil deeds of Joseph's brothers against him when they conspired against him and sold him into slavery. With this inspiring technique, the narrator recreates the past into the present through which the reader experiences the world of the story. It is interesting to note that the narrator of this ancient literary composition of Joseph's reconciliation with his brothers got them acquitted as he downplayed the gravity of their filial crime against Joseph. Expressing this clearly, the narrator in verse 5 intones thus

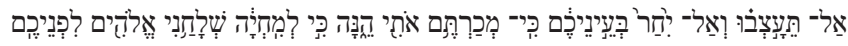
('[d]o not be grieved or annoyed with yourselves that you sold me for God sent me before you to save life'). Arguably, the above expression of Joseph brings to the present the past filial crime of the brothers against him, as it furnishes the reader with such ugly episode. However, he assuaged the severity of their evil act against him and elucidated the whole affair theologically. It is obvious that the brothers intended evil against him but God has reversed it into good. The sidestepping motive of the narrator in Genesis 39 that God was with Joseph and made him attract favour from his superiors was retrospectively fulfilled in Genesis 45:5-8. God sent him ahead of his brothers in Egypt (Gn 37) so that through him, the descendants of Israel would be saved from the great famine and thus cause them a great escape (Odo 2013:55).

An assessment of the words of Joseph in verses 4-8 portrays his forgiveness to the brothers. There is a discovery of two Hebrew words in verse 7 of the pericope that are difficult to interpret. These words are פְּרָרֵית (remnant and survivours). Skinner (1976:487) posited that the term, פשִארֵית (remnant), perhaps could be seen in the sense of descendants. However, the use of פִּלָיטָה to mean 'escaped remnant' is difficult, seeing that the whole family was saved. According to Kidner (1967:207), 'Joseph's words, a remnant and a great deliverance, emphasise the peril it had escaped, one of the Old Testament's many crises of judgment and salvation'. A thorough study of the word i⿱ שָארית in the first five books of the Old Testament discloses that it occurs only once in the whole of the Pentateuch. Its place of occurrence is in Genesis 45:7. Apart from this place, it occurs in pairs with a word פְּלָיטָ in Isaiah 37:32, Ezra 9:14, 1 Chronicles 4:43 and 2 Kings 19:31. Maintaining this line of argument, Westermann (1986) affirmed that the word שִֵֵׁית occurs only here in the Pentateuch. Speaking further, he opined that the words, remnant and saved (or survivors), occur predominantly only in the prophets as he argues that the second part of the above verse 7 which contains פְּלָיטָה is a later addition. The theology 
that punctuated Joseph's narrative was enshrined in Joseph's words to his brothers. He explained to them that their act of selling him out into slavery was God's doing (Richard \& Roland 2000:40). Acquitting the brothers of their evil act against him, Joseph explained to them that God willed his people into Egypt to save life (Amos 2006:13). The theological theme of God's deliverance and rescue to his people, which adores Joseph's narrative, is a frequent motif in the entire narrative composition of Genesis (Von Rad 1963:393). It seems obvious that the overriding power of God's rule is not a vacuous sovereignty. Its purpose is to feed a people. This hidden God has a quite identifiable historical purpose. And though that purpose is worked out with reference to imperial power and well-being, his goal is the creation of a community of liberation (Brueggemann 2010:294).

The third division of the text contains verses $9-13$, and it is enveloped in Joseph's imperative to the brothers to go back home and bring his father. He charged them to tell his father of all the respect that he commands in Egypt. Examining closely the first Hebrew verb that kicks off verse 13 of the pericope identifies that the word וְ is laced with imperative.

The text of Genesis 45:1-15 attains its structural apogee in the fourth part of the text's division (vv. 14-15) when Joseph fell upon Benjamin's neck and wept, and afterwards, reconciled with his brothers in a symbolic way as he kissed all of them passionately. A close study of the word 14 and 15 discloses that the word is apocopated in construction. Admittedly, it is a shortened form of a Hebrew word דָָּ which means 'to weep'. Reading in-between lines of the last unit of the pericope unfolds that Joseph's reconciliation with his brothers was symbolically exhibited. He kissed all of them and wept. It was after this symbolic reunion that his brothers became at ease with him and thus spoke with him. Joseph acquitted his brothers and they were reconciled (vv. 14-15). This affectionate demonstration of Joseph obviously underscores his hearty reconciliation to the brothers (Gill 2020:1; Guzik 2020:3). The brothers became at ease and talked with him only when he had wept and kissed them all affectionately showing how the situation of Chapter 37 had been reversed.

\section{Synthesis}

The exegesis has shown that Genesis 45:1-15, which revolves around Joseph's story and his reconciliation with his brothers, is encoded in a device of retrospective narrative. This is found in verses $4-8$ of the pericope where the narrator looks back and recreates the filial crime of the brothers against him in Genesis 37. Employing this astonishing device, the narrator smartly and politely communicates the brothers' evil act against Joseph to the reader. However, Joseph assuaged the severity of their heinous act and explained it theologically that although they intended to do him evil, God reversed the situation for salvific purposes.

\section{Conclusion}

A critical survey of the story of Joseph's narrative in the Old Testament identified paternal favouritism of Jacob on Joseph over his siblings as the major factor that led to the catastrophe that engulfed Joseph's early life. The surging acrimony emanating from the embittered brothers beclouded their moral probity, as they impinged on Joseph's right to life and had him sold into slavery in Genesis 37. Employing the device of a retrospective narrative, the article argues that the narrator of Joseph's reconciliation with his brothers in Genesis 45 looks back into a filial crime of the brothers as he politely recreates the past evil deeds of Joseph's brothers against him to the reader.

\section{Acknowledgements Competing interests}

The author declares that he has no financial or personal relationships that may have inappropriately influenced him in writing this article.

\section{Author's contributions}

D.O.O. is the sole author of this article.

\section{Ethical considerations}

This study followed all ethical standards for research without any direct contact with human or animal subjects.

\section{Funding information}

This research work received no specific grant from any funding agency in the public, commercial or not-for-profit sectors.

\section{Data availability}

Data sharing is not applicable to this article as no new data were created or analysed in this study.

\section{Disclaimer}

The views and opinions expressed in this article are those of the author and do not necessarily reflect the official policy or position of any affiliated agency of the author.

\section{References}

Alter, R., 1981, The art of biblical narrative, Basic Books, New York, NY.

Amos, C., 2006, 'The Genesis of reconciliation: The reconciliation of Genesis', Journa of the International Association for Mission Studies 23(1), 9-26. https://doi. org/10.1163/157338306777890466

Barry, M., 1970, 'Retrospective narrative in nineteenth century American literature', College English 31(41), 366-375. https://doi.org/10.2307/374543

Bran, N., 1996, 'Anticipating retrospective: The first person retrospective novel and Iris Murdoch's the Sea', The Sea Journal of Narrative Technique 26(2), 187-208.

Bridge, E.J., 2019, 'Polite rhetoric: Judah's plea to Joseph in Genesis 44.18-34', Journal for the Study of the Old Testament 43(4), 571-587. https://doi.org/10.1177/ 0309089218762284

Brien, O., 1997, 'The contribution of Judah's speech, Genesis 44:18-34, to the Characterization of Joseph', Catholic Biblical Quarterly 59, 429-447. 
Brodier, T.L., 2001, Genesis as dialogue: A literary, historical and theological commentary, Oxford University Press, Oxford.

Bruce, F., 1986, Jesus: Lord Saviour, InterVarsity Press, Downers Grove, IL.

Brueggemann, W., 2010, Genesis, interpretation: A Bible commentary for teaching and preaching, Westminster John Knox Press, Louisville, KY.

Carson, D., 2007, New Bible commentary, InterVarsity Press, Downers Grove, IL.

Culpepper, R.A., 1998, The Gospel and Letters of John, Abingdon Press, Nashville, TN.

DeJonge, H., 2020, Beyond the Lectionary Text: Genesis 45, viewed 10 September 2020, from https://cep.calvinseminary.edu/non-rcl-starters/genesis-45/.

Deffinbaugh, R.L., 2020, The fundamentals of forgiveness (Genesis 45:1-28), viewed 10 September 2020, from https://bible.org/seriespage/fundamentalsforgiveness-genesis-451-28.

Duke, P.D., 1985, Irony in the Fourth Gospel, John Knox Press, Atlanta, GA.

Gill, D., 2020, 'Genesis 45', John Gill's Exposition of the Bible, viewed 30 May 2020 from https://www.biblestudytools.com/commentaries/gills-exposition-of-thebible/genesis-45-15.html.

Guzik, D., 2020, 'Genesis 45 - Joseph is reunited with his brothers', The Enduring Word Bible Commentary, viewed 30 May 2020, from https://enduringword.com/biblecommentary/genesis- 45 .

Hale, T., 2007, The applied Old Testament commentary: Applying God's word to your life, David C Cook Publishing Company, New York, NY.

Heffelfinger, K.M., 2016, 'From Bane to blessing: The food leitmotif in Genesis 37-50', Journal for the Study of Old Testament 40(3), 297-320. https://doi. org/10.1177/0309089215622364

Joosten, J., 2016, 'Biblical rhetoric as illustrated by Judah's speech in Genesis 44.18-34', Journal for the Study of Old Testament 41(1), 15-30. https://doi. org/10.1177/0309089216628417

Kannel, B., 2015, The plan: The life of Joseph and the providence of God, York Alliance Church, Phillipsburg.

Kidner, D., 1967, Genesis: An introduction and commentary, InterVarsity Press, Chicago, IL.

Kori, M., 2021, The definition of retrospective narrative, viewed 04 May 2021, from https://education.seattlepi.com/definition-retrospective-narrative-5291.html.
Kraut, J., 2019, 'The literary roles of Reuben and Judah in Genesis narratives: A "reflection complex"', Journal for the Study of Old Testament 43(2), 205-227. https://doi.org/10.1177/0309089217711029

Krusschwitz, J., 2012, 'The type-scene connection between Genesis 38 and the Joseph story', Journal for the Study of Old Testament 36(4), 383-410. https://doi. org/10.1177/0309089212438003

Lambe, J., 1999, 'Judah's development: The pattern of departure transition-return', Journal for the Study of Old Testament 24(83), 53-68. https://doi.org/10.1177/ 030908929902408304

Lindvall, M., 2013, 'Between text and Sermon Genesis 45:1-11, 15', Interpretation: A Journal of Bible and Theology 67(3), 281-283. https://doi.org/10.1177/002 0964313483437

Mandlfo, C., 2004, “'You meant evil against me": Dialogic truth and the character of Jacob in Joseph's story', Journal for the Study of Old Testament 28()4, 449-465. https://doi.org/10.1177/030908920402800404

Mundele, A., 2012, A handbook on African approaches to biblical interpretation, Kolbe Press, Lumuru.

Odo, D., 2013, 'Joseph's reconciliation with his brothers: A study of Genesis 45:1-15 in the Nigerian context', MA thesis Submitted to the Department of Religion and Cultural Studies, University of Nigeria, Nsukka.

Pen and Pad, 2020, Retrospective narrative, viewed 15 April 2021, from https:// penandthepad.com/definition-retrospective-narrative-12303373.html.

Richard, J. \& Roland, E., 2000, 'Genesis', in E. Raymond et al. (eds.), The new Jerome biblical commentary, pp. 8-43, Geoffery Chapman, Englewood Cliffs, NJ.

Selgin, P., 2019, Looking back: A retrospective narrative that appeals to the senses, viewed 23 April 2021, from https://www.janefriedman.com/retrospective-narrative/.

Ska, J.I., 1991, 'Our fathers have told us', Introduction to the analysis of Hebrew narratives, Subsidia Biblica, Pontificio Istituto Biblico, Rome.

Skinner, J., 1976, The international critical commentary. A critical and exegetical commentary on Genesis, T and T Clark Ltd., Edinburgh.

Von Rad, G., 1963, Genesis: A commentary, SCM Press, London.

Wenham, G., 2003, Exploring the Old Testament: Volume 1-The Pentateuch, SPCK, Great Britain, London.

Westermann, C., 1986, Genesis 37-50: A commentary, Augsburg Publishing House, London. 